\title{
Changes in the Composition and Abundance of Phytoplankton in a Coastal Lagoon of Baja California, México, during 2011
}

\author{
María Fernanda Gracia-Escobar ${ }^{1}$, Roberto Millán-Núñez ${ }^{1 *}$, Enrique Valenzuela-Espinoza², \\ Adriana González-Silvera1, Eduardo Santamaría-del-Ángel1 \\ ${ }^{1}$ Facultad de Ciencias Marinas, Universidad Autónoma de Baja California, Ensenada, México \\ ${ }^{2}$ Instituto de Investigaciones Oceanológicas, Universidad Autónoma de Baja California, Ensenada, México \\ Email: rmillan@uabc.edu.mx
}

Received 25 February 2015; accepted 20 March 2015; published 24 March 2015

Copyright (C) 2015 by authors and Scientific Research Publishing Inc.

This work is licensed under the Creative Commons Attribution International License (CC BY).

http://creativecommons.org/licenses/by/4.0/

(c) (i) Open Access

\section{Abstract}

A time series with weekly sampling was conducted from February 20, to December 16, 2011 at a station in the interior of the San Quintín Bay to estimate seasonal changes in the composition and abundance of phytoplankton. Water temperature was recorded and the upwelling index was calculated for the period. Phytoplankton abundance was estimated and phytoplankton were identified by using an inverted microscope and the CHEMTAX program. There were 16 positive phytoplankton anomalies during the year, but only three were considered to be blooms. The blooms were dominated by diatoms and were recorded in the winter, spring and summer. Different genera composed $80 \%$ of the total phytoplankton abundance of each of the blooms. The first bloom consisted of diatoms of the genera Pseudo-nitzschia sp. (15.7\%), Skeletonema sp. (14.6\%), Eucampia sp. (7\%), and Navicula sp. (7\%); a haptophyte of the genus Imantonia sp. (13.1\%); and dinoflagellates of the genus Prorocentrum sp. (4.6\%). The second bloom consisted mainly of diatoms of the genera Guinardia sp. (30.6\%), Pseudo-nitzschia sp. (21.5\%), Skeletonema sp. (14.5\%), Chaetoceros sp. (8.4\%) and Eucampia sp. (5.3\%). The third bloom consisted of Chaetoceros sp. (46.3\%), Pseudo-nitzschia sp. (22.6\%), Skeletonema sp. (7.29\%), and Imantonia sp. (6\%). Dinoflagellates were observed in the winter, summer and autumn, but they contributed less biomass than diatoms. Prorocentrum sp., Gymnodinium sp., and Ceratium sp. were among the dinoflagellates that were observed. The differences in abundance and composition of phytoplankton groups in the blooms in San Quintín Bay during 2011 were due primarily to seasonal changes in the physical and chemical factors of the seawater and to upwelling events.

\footnotetext{
${ }^{*}$ Corresponding author.
}

How to cite this paper: Gracia-Escobar, M.F., Millán-Núñez, R., Valenzuela-Espinoza, E., González-Silvera, A. and Santamaría-del-Ángel, E. (2015) Changes in the Composition and Abundance of Phytoplankton in a Coastal Lagoon of Baja California, México, during 2011. Open Journal of Marine Science, 5, 169-181. http://dx.doi.org/10.4236/ojms.2015.52014 


\section{Keywords}

\section{Phytoplankton, Bloom, Pigments, CHEMTAX, Coastal Lagoon}

\section{Introduction}

Phytoplankton is one of the main primary producers in marine environments. They are part of the food chain of many marine ecosystems and are the main source of food for native and cultivated filter feeders in coastal lagoons. In the interior of the San Quintín Bay, Baja California, México (SQB), the phytoplankton have been studied by using time series with intervals of hours, days and weeks during different periods of the year [1]-[7]. These studies were focused on phytoplankton composition in the interior of the lagoon. The identification and quantification of phytoplankton were performed using an inverted microscope, which is time consuming, requires experience and is limited to identifying cells that are larger than $5 \mu \mathrm{m}$. A scanning electron microscope, an epifluorescence microscope and/or flow cytometry are used to identify cells that are smaller than $5 \mu \mathrm{m}$ [8]. The contribution of the different groups of phytoplankton, including pico- and nanoplankton fractions, to total chlorophyll $a$ (TChla) can be derived from pigments and is determined by high-performance liquid chromatography (HPLC) and the software CHEMTAX [9]. Millán-Núñez et al. (2004) [10] studied the phytoplankton community by analyzing pigments and using CHEMTAX program. The data that were used in their study were obtained with a 24-hour time series that was conducted during April, 2011 at a station located in SQB. The main conclusions were that cryptophytes, cyanophytes, bacillariophytes (diatoms) and chlorophytes were present in higher quantities in the mouth of the bay and decreased in number toward the interior of the bay. Their study also reported for the first time the value of the concentration of divinyl Chla (DvChla) and the presence of the genus Prochlorococcus sp., which is common in oligotrophic waters [11].

Moreno-Miranda (2007) [6] assessed the quantity of phytoplankton in SQB by using CHEMTAX in May, 2004 and found that cryptophytes, bacillariophytes and dinoflagellates of the class Dinophyceae were the most abundant groups. Cryptophytes were more abundant at all sampling locations, but bacillariophytes and representatives of the Dinophyceae decreased in quantity from the mouth to the interior of the lagoon. In October of the same year, [7] reported minor quantities of phytoplankton in the interior of the lagoon and that cryptophytes were more abundant than bacillariophytes and chlorophytes. Because there have been few long-term studies in $\mathrm{SQB}$, the present paper was intended to assess changes in the abundance and composition of phytoplankton at a location in the main channel of the lagoon during 2011. Changes in the abundance and composition of phytoplankton in response to seasonal changes in the physicochemical variables of seawater were of particular interest.

\section{Materials and Methods}

\section{Study Area}

San Quintín Bay (SQB) is a Y-shaped coastal lagoon with an approximate area of $42 \mathrm{~km}^{2}$. The west branch is known as Falsa Bay, and the east branch is known as San Quintín Bay [12]. The coastal lagoon is located in a semi-arid area in the northern part of the Baja California peninsula in México. The depth of the lagoon ranges from 10 to $12 \mathrm{~m}$ at the mouth and from 6 to $8 \mathrm{~m}$ in the main channels, and it tends to decrease toward land (Figure 1). There is a constant exchange of water between SQB and the Pacific Ocean by means of currents and tidal flows through the mouth of the lagoon, where the lagoon and ocean meet. The tide is semi-diurnal and has amplitudes of $0.7 \mathrm{~m}$ during low tide and $3.5 \mathrm{~m}$ during high tide. [4] [13] have reported upwelling during spring and summer in waters that are adjacent to SQB.

Seawater samples were collected at a depth of $30 \mathrm{~cm}$ with black 4-liter Nalgene high-density bottles at a location in the main channel of Falsa Bay (Figure 1). Sampling was carried out weekly from February to December, 2011. To analyze the phytoplankton, samples of $250 \mathrm{~mL}$ of water were preserved in a 1:100 v/v neutral Lugol's solution that had been prepared with sodium acetate. The samples were stored in a dark cool location until they were analyzed in laboratory. The method that was described by Utermöhl (1958) [14] and modified by the Intergovernmental Oceanographic Commission of UNESCO (2010) [15] was used to quantify and determine the amount of phytoplankton. Samples of 25 mL were placed into an Utermöhl chamber (Hydro-Bios, Kiel Alten- 


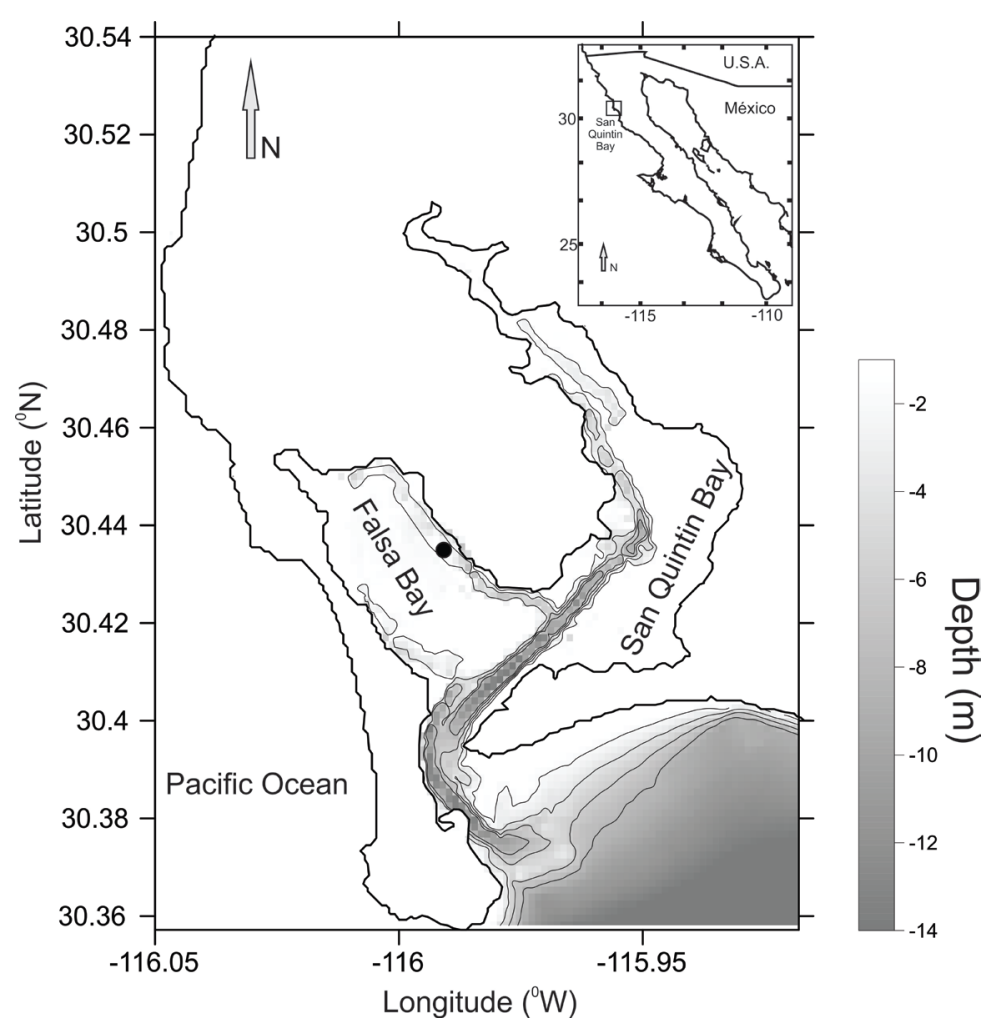

Figure 1. Study area and sampling location $(\bullet)$.

holz, Germany) for 24 hours. The phytoplankton at the bottom of the chamber were identified and counted by using an inverted microscope (Carl Zeiss, Jena, Germany) with phase contrast. Nanoplankton organisms ( $>5 \mu \mathrm{m})$ and microplankton $(>20 \mu \mathrm{m})$ were counted and identified at $400 \times$ and $200 \times$ magnifications. Organisms that were larger than $30 \mu \mathrm{m}$ and were present in smaller quantities were counted at a $100 \times$ magnification [16]. Organisms that occurred in colonies or chains were counted individually.

To perform the pigment analysis, $1 \mathrm{~L}$ of seawater was filtered with GF/F filters that were $25 \mathrm{~mm}$ in diameter. The filters that contained the sample were folded, placed onto foil paper and stored in liquid nitrogen until they were analyzed in the laboratory. Pigment extraction was carried out in $12 \mathrm{~mL}$ centrifuge tubes for $24 \mathrm{~h}$ with a 5-mL 100\% acetone solution that contained Trans Beta Apo-carotenal as an internal standard. The pigment extract was filtered by using $0.2-\mu \mathrm{m}$ acrodisc filters and injected into a high-performance liquid chromatography (HPLC) apparatus (Varian, Washington DC, USA) that was equipped with a Hypersil MOS2 RP-C8 column $(150 \times 4.6 \mathrm{~mm}$ and $3.5 \mu \mathrm{m}$ particle size). A two-solvent gradient system was used as described by Barlow et al. (1997) [17]. The solvents were 70:30 v/v methanol with $1 \mathrm{M}$ ammonium acetate $(\mathrm{v} / \mathrm{v})$ and the solvent B methanol $100 \%$ at a flow rate of $1 \mathrm{~mL} \cdot \mathrm{min}^{-1}$. The pigment standards that were used in the HPLC were acquired from Sigma-Aldrich (St. Louis, Missouri, USA) and DHI (Denmark). The concentration of the standards was determined by a spectrophotometer that used the extinction coefficients that were proposed by Jeffrey et al. (1997) [18]. The pigment standards were used to identify the absorption peaks in the chromatogram.

The contributions of diatoms, dinoflagellates, cryptophytes, chlorophytes, prymnesiophytes, prasinophytes, cyanophytes and prochlorophytes to the total Chla (TChla) were assessed by using the software CHEMTAX [9]. TChla is the result of the addition of the concentrations of chlorophyll-a that were determined by HPLC, including allomers and epimers of chlorophyll and monovinyl and divinyl chlorophyll-a. CHEMTAX makes use of three matrices. Matrix 1 contains the pigment concentration in the samples. Matrix 2, which is an initial matrix, contains the amount of accessory pigment and Chla for each algal group that is found in the sample. Matrix 3 defines the accessory pigment limits of the Chla relationship. Matrix 2 includes the phytoplankton groups that had been identified previously in SQB by means of a microscope (Table 1). The necessary amount of the accessory pigment Chla was determined by consulting previous reports for SQB [10] and for other locations [9] [19]. 
Table 1. Pigment:chlorophyll ratio used in CHEMTAX: (a) Initial matrix, and (b) Final matrix. Chlc3, chlorophyll c3; Chl c2, chlorophyll c2; Peri, peridinin; But, 19’Butanoloxyfucoxanthin; Fuco, fucoxanthin; Prasi, prasinoxanthin; Viol, violoxanthin; Hex, 19'Hexanoloxyfucoxanthin; Diad, diadinoxanthin; Allo, Aloxanthin; Diat, diatoxanthin; Zea, zeaxanthin; Lut, lutein; Chl b, chlorophyll b; and DvChla, divinyl chlorophyll $a$.

\begin{tabular}{|c|c|c|c|c|c|c|c|c|c|c|c|c|c|c|c|}
\hline (a) & Chlc3 & Chlc2 & Peri & But & Fuco & Prasi & Viol & Hex & Diad & Allo & Diat & Zea & Lut & Chlb & DvChla \\
\hline Diatoms & & 0.287 & & & 0.400 & & & & 0.126 & & 0.035 & & & & \\
\hline Dinoflagellates & & 0.034 & 0.155 & & & & & & 0.114 & & 0.027 & & & & \\
\hline Haptophytes & 0.056 & 0.136 & & 0.003 & 0.217 & & & 0.255 & & & 0.031 & & & & \\
\hline Chlorophytes & & & & & & & & & & & & 0.003 & 0.011 & 0.247 & \\
\hline Chryptophytes & & 0.085 & & & & & & & & 0.172 & & & & & \\
\hline Prasinophytes & & & & & & 0.092 & 0.070 & & & & & & 0.004 & 0.500 & \\
\hline Cyanophytes & & & & & & & & & & & & 0.283 & & & \\
\hline Prochlorophytes & & & & & & & & & & & & 0.146 & & & 1.0 \\
\hline \multicolumn{16}{|l|}{ (b) } \\
\hline Diatoms & & 0.101 & & & 0.392 & & & & 0.054 & & 0.023 & & & & \\
\hline Dinoflagellates & & 0.030 & 0.135 & & & & & & 0.151 & & 0.023 & & & & \\
\hline Haptophytes & 0.035 & 0.106 & & 0.002 & 0.160 & & & 0.216 & & & 0.019 & & & & \\
\hline Chlorophytes & & & & & & & & & & & & 0.002 & 0.009 & 0.144 & \\
\hline Chryptophytes & & 0.093 & & & & & & & & 0.280 & & & & & \\
\hline Prasinophytes & & & & & & 0.054 & 0.036 & & & & & & 0.001 & 0.268 & \\
\hline Cyanophytes & & & & & & & & & & & & 0.261 & & & \\
\hline Prochlorophytes & & & & & & & & & & & & 0.051 & & & 0.468 \\
\hline
\end{tabular}

The temperature of the seawater in each sample was measured using a bucket thermometer that had an accuracy of $\pm 0.1^{\circ} \mathrm{C}$. Wind direction and velocity were obtained for the whole year from a weather station that was located in the northern part of the bay.

\section{Results}

Water temperature in the sampling site ranged from $15.2^{\circ} \mathrm{C}$ to $21.2^{\circ} \mathrm{C}$ winter half (week 7) to late autumn (week 49), then decreasing to $14^{\circ} \mathrm{C}$ (Figure 2(a)). The prevailing wind direction was northwest during most of the time series. Wind velocity reached a maximum of $6 \mathrm{~m} \cdot \mathrm{s}^{-1}$ and decreased to $3 \mathrm{~m} \cdot \mathrm{s}^{-1}$ at the end of the year (Figure 2(b)). The upwelling index was calculated from the wind direction and wind velocity according to the methodology that was described by Pérez-Brunius et al. (2007) [20] (Figure 2(c)). During the spring and summer, the values of the upwelling indices ranged from 60 to $90 \mathrm{~m}^{3} \cdot \mathrm{s}^{-1}$ per $100 \mathrm{~m}$ coastline, when the wind speed was higher than $5 \mathrm{~m} \cdot \mathrm{s}^{-1}$ and temperature values were low. In the autumn and winter, the index values were lower than $40 \mathrm{~m}^{3} \cdot \mathrm{s}^{-1}$ per $100 \mathrm{~m}$ coastline, when wind velocities were under $5 \mathrm{~m} \cdot \mathrm{s}^{-1}$.

\subsection{Abundance of Phytoplankton}

The microscopically determined quantity of micro and nanophytoplankton groups varied throughout the year and had a maximum cell density of $29.6 \times 10^{3} \mathrm{cell} \cdot \mathrm{L}^{-1}$. Diatoms were the most abundant group, followed in decreasing order of abundance by cryptophytes, prymnesiophytes, prasinophytes, chlorophytes, and dinoflagellates (Figure 3). Smayda (1997) [21] defines a phytoplankton bloom (B) as a significant increase in biomass that is expressed in terms of cell density or chlorophyll concentration. The term minibloom is used to refer to a moderate increase in phytoplankton biomass that occurs during a short period [21] [22]. To determine which samples corresponded to an algal bloom, the standardized anomalies of total phytoplankton were obtained by using Z-scores. A Z-score is the number of standard deviations that an observation or datum falls above the mean: 

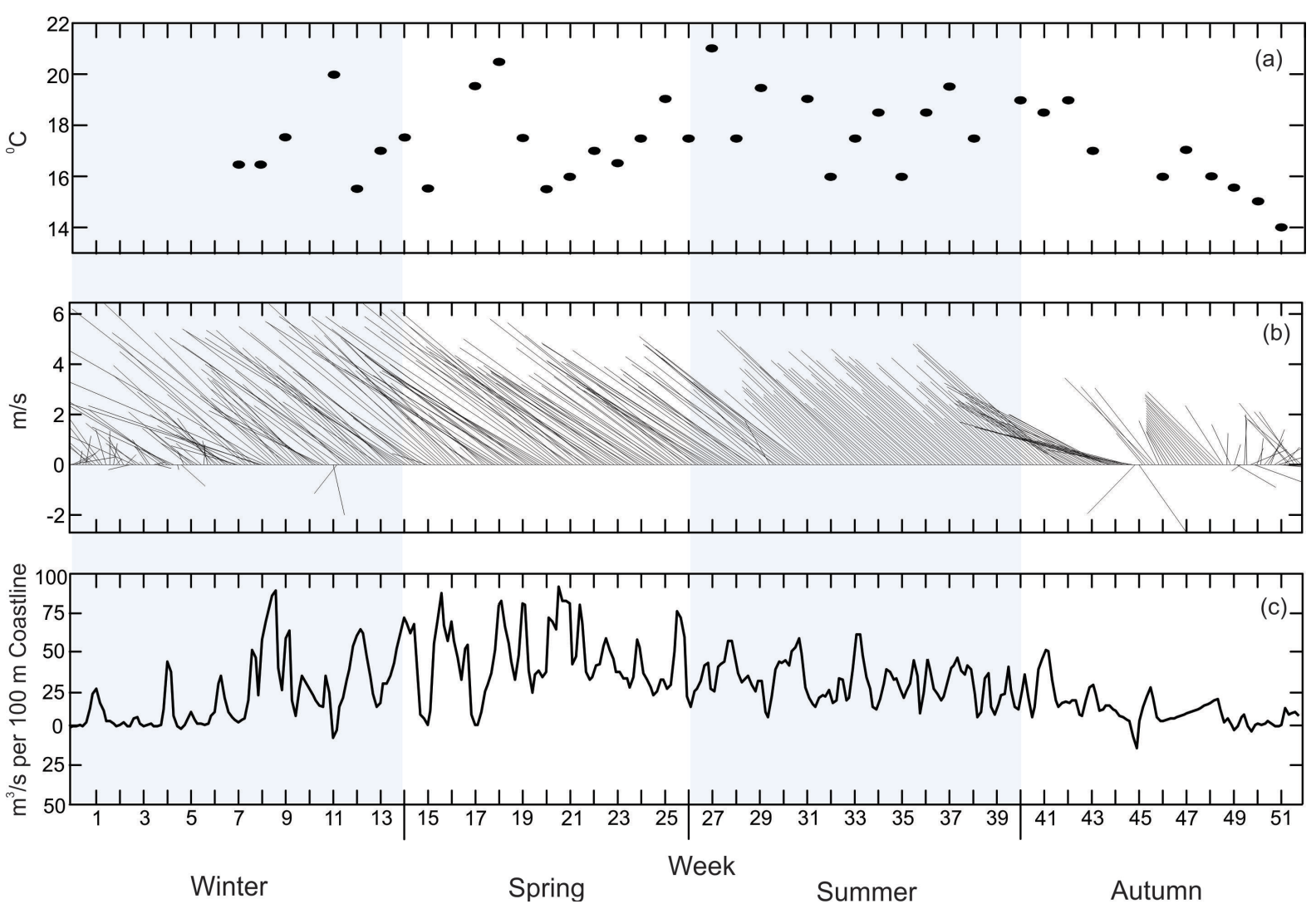

Figure 2. Sea surface temperature at the sampling site (a); Direction and wind velocity for 2011 as collected from a weather station that was located in the northern part of San Quintin Bay (b); Upwelling index for 2011 in the adjacent area to San Quintín Bay (c).

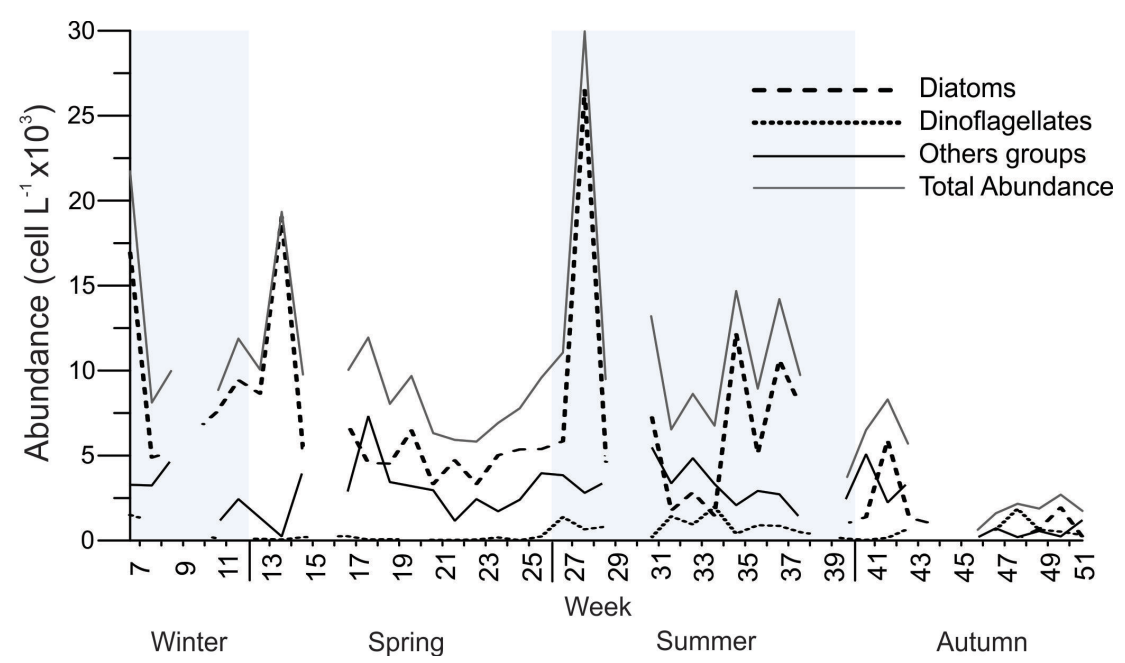

Figure 3. Abundance of diatoms, dinoflagellates, other groups and total abundance for weekly sampling in 2011.

$$
Z=\frac{X-\bar{X}}{S D}
$$

where: $Z$ is the standard score, $X$ is the observed variable, and $\bar{X}$ and $S D$ are the mean and standard deviation, respectively.

There were 16 positive z-scores in the sampling series for the quantity of phytoplankton that was observed for 
total phytoplankton abundance (PATA) (Figure 4(a)). Most PATA coincided with positive z-scores of diatoms, cryptophytes and chlorophytes (Figure 4(b)). However, the dinoflagellates had positive z-scores that coincided with PATA 1, 10, 11 and 15 (Figure 4(c)). Although there were positive scores for other dinoflagellate samples during the summer and autumn, they were more abundant relative to the average variation and the positive scores did not coincide with any PATA. There were positive z-scores for chlorophytes and cryptophytes during the spring, summer and the beginning of autumn, which contributed to PATA 3, 6 - 10 and 12 - 16 (for chlorophytes) and (6 - 10, 12 and 16) (for cryptophytes) (Figure 4(d), Figure 4(e)). There were positive z-scores for haptophytes in the winter, summer and the beginning of autumn, which contributed only to PATA $1-4,10-12$ and 14 (Figure 4(f)). There were 16 PATA in SQB during 2011, of which only three had z-scores that were greater than 1.66 standard deviations (90\% confidence level) and were considered to be blooms (B). These blooms presented cell concentrations that were greater than $16.9 \times 10^{3}$ cell. $\mathrm{L}^{-1}$ in the winter, spring and summer (Figure 4(a)). The three blooms differed in the number of cells, group composition and phytoplankton genera that were present (Figures 5(a)-(h)). The genera that were considered to be predominant during the blooms were those that accounted for $80 \%$ or more of the total number of cells in the sample. The first bloom (B1) occurred during the winter (in February) (Figure 4(a)) and consisted of the diatoms Pseudo-nitzschia sp. $\left(3.4 \times 10^{3}\right.$ cell $\left.\cdot \mathrm{L}^{-1}\right)$, Skeletonema sp. $\left(3.16 \times 10^{3}\right.$ cell $\left.\cdot \mathrm{L}^{-1}\right)$, Eucampia sp. $\left(1.52 \times 10^{3}\right.$ cell $\left.\cdot \mathrm{L}^{-1}\right)$ and Navicula sp. $\left(1.56 \times 10^{3}\right.$ cell $\left.\cdot \mathrm{L}^{-1}\right)$, the haptophyte Imantonia sp. $\left(2.84 \times 10^{3}\right.$ cell $\left.\cdot \mathrm{L}^{-1}\right)$ and the dinoflagellate Prorocentrum sp. $\left(1.0 \times 10^{3}\right.$ cell $\cdot \mathrm{L}^{-1}$ ). (Figures 5(a)-(e)). The second bloom (B2) occurred during the spring (in April) (Figure 4(a)) and consisted of the diatoms Guinardia sp. $\left(5.92 \times 10^{3} \mathrm{cell} \cdot \mathrm{L}^{-1}\right)$, Pseudo-nitzschia sp. $\left(4.16 \times 10^{3} \mathrm{cell} \cdot \mathrm{L}^{-1}\right)$, Skeletonema

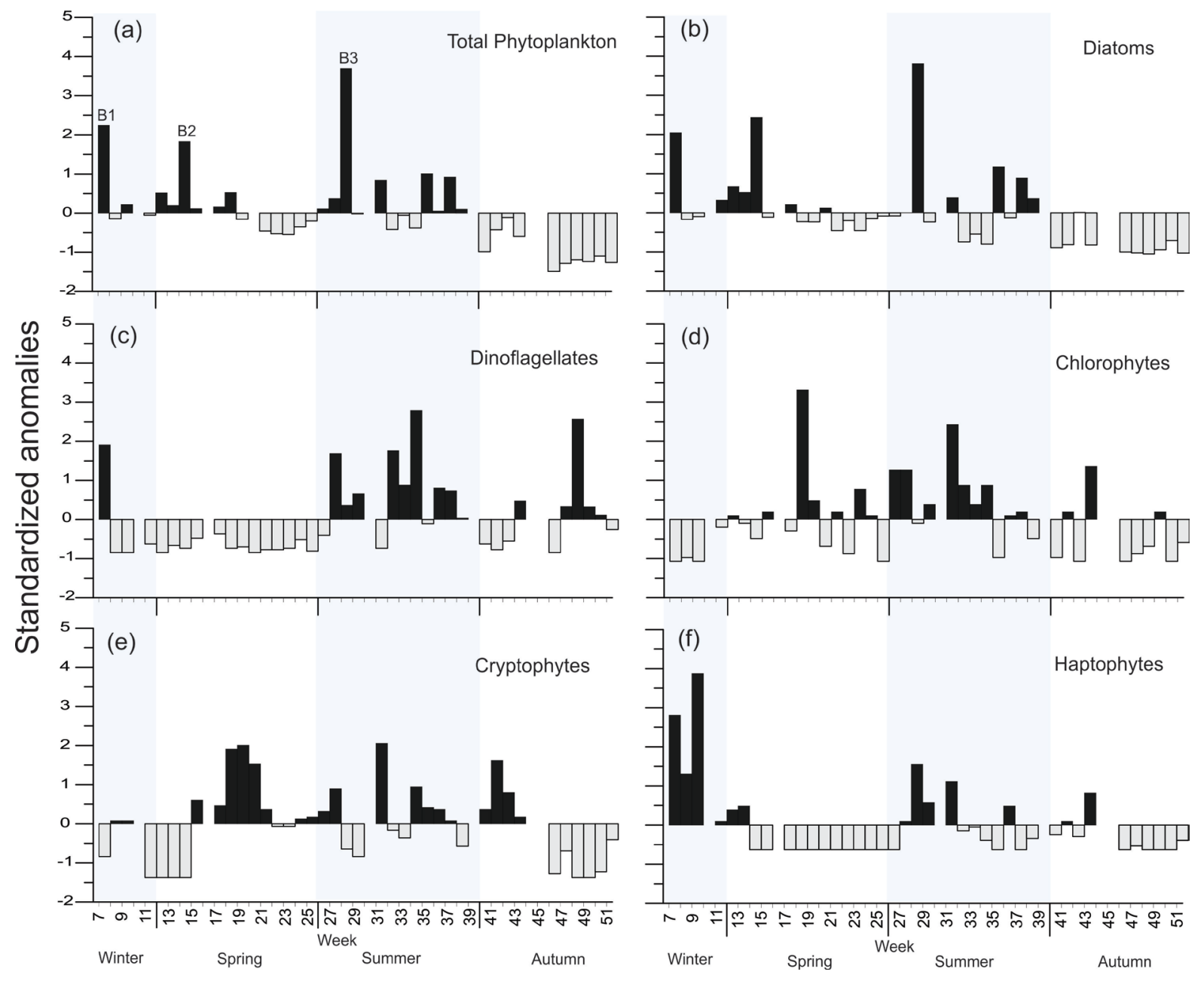

Figure 4. Standardized anomalies for phytoplankton groups in San Quintín Bay for weekly sampling in 2011. Total phytoplankton (a), diatoms (b), dinoflagellates (c), chlorophytes (d), cryptophytes (e), haptophytes (f). 

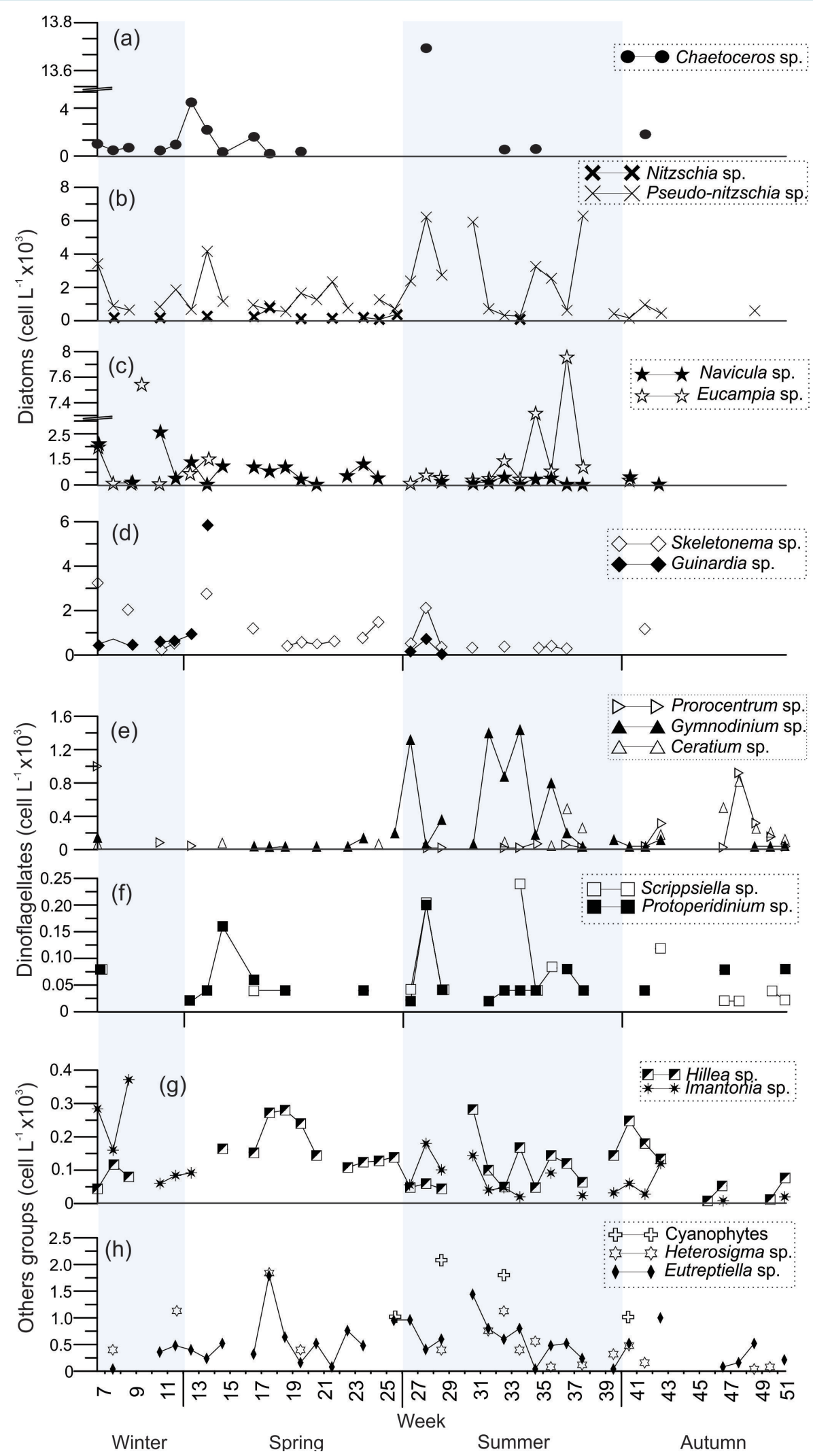

Figure 5. Phytoplankton abundance enumerate by microscopy for weekly sampling in 2011. Diatoms (a)-(d), dinoflagellates (e) (f), cryptophytes and haptophytes (g), cyanophytes, raphidophytes and chlorophytes (h). 
sp. $\left(2.8 \times 10^{3}\right.$ cell $\left.\cdot \mathrm{L}^{-1}\right)$, Chaetoceros sp. $\left(1.64 \times 10^{3}\right.$ cell $\left.\cdot \mathrm{L}^{-1}\right)$ and Eucampia sp. $\left(1.04 \times 10^{3}\right.$ cell $\left.\cdot \mathrm{L}^{-1}\right)($ Figure 5(b), Figure 5(d)). The third bloom (B3) occurred in mid July (Figure 4(a)). B3 had the largest number of phytoplankton cells of the three blooms and consisted of Chaetoceros sp. $\left(13.72 \times 10^{3}\right.$ cell $\left.\cdot \mathrm{L}^{-1}\right)$, Pseudo-nitzschia sp. $\left(6.2 \times 10^{3}\right.$ cell $\left.\cdot \mathrm{L}^{-1}\right)$ and Skeletonema sp. $\left(2.16 \times 10^{3}\right.$ cell $\left.\cdot \mathrm{L}^{-1}\right)$ (Figures $\left.5(\mathrm{a})-(\mathrm{c})\right)$ and the haptophyte Imantonia sp. $\left(1.8 \times 10^{3}\right.$ cell $\left.\cdot \mathrm{L}^{-1}\right)$ (Figure $5(\mathrm{~g})$ ). In addition to the diatoms that were found in the three blooms, other genera, such as Gyrosigma sp., Cocconeis sp., Thalassiosira sp. and Pleurosigma sp, were present in smaller numbers.

The cell densities of the diatoms (maximum values of $1.3 \times 10^{3}, 1.78 \times 10^{3}$ and $1.74 \times 10^{3} \mathrm{cell} \cdot \mathrm{L}^{-1}$ in the winter, summer and autumn, respectively) were greater than those of the dinoflagellates (Figure 5(e), Figure 5(f)). The highest cell densities were shown by the genera Prorocentrum sp. $\left(1.0 \times 10^{3}\right.$ cell. $\left.\mathrm{L}^{-1}\right)$ in the winter, Gymnodinium sp. $\left(1.44 \times 10^{3}\right.$ cell. $\left.\mathrm{L}^{-1}\right)$ in the summer and Prorocentrum sp. $\left(0.92 \times 10^{3} \mathrm{cell} \cdot \mathrm{L}^{-1}\right)$ and Ceratium sp. $(0.82$ $\times 10^{3}$ cell $\left.\cdot \mathrm{L}^{-11}\right)$ in the autumn. Cell density was low in the spring, when values of $\left(0.175 \times 10^{3} \mathrm{cell} \cdot \mathrm{L}^{-1}\right)$ were observed for Protoperidinium sp. (Figure 5(e), Figure 5(f)). Cell densities of $0.04 \times 10^{3} \mathrm{cell} \cdot \mathrm{L}^{-1}$ for the genus Dictyocha sp, which belongs to the order silicoflagellates, were observed in two samples that were collected at the end of the sampling period. Cryptophytes were found throughout most of year and reached cell densities of $2.72 \times 10^{3}$ cell $\cdot \mathrm{L}^{-1}$ in the spring, $2.84 \times 10^{3}$ cell $\cdot \mathrm{L}^{-1}$ in the summer and $2.5 \times 10^{3} \mathrm{cell} \cdot \mathrm{L}^{-1}$ in the early autumn. However, the cryptophytes cell density was lower than $1.2 \times 10^{3} \mathrm{cell} \cdot \mathrm{L}^{-1}$ ) in the winter (Figure $5(\mathrm{~g})$ ). The highest cryptophyte cell densities were recorded for the genus Hillea sp. (Figure 5(g)) and occasionally the genus Leucocryptos sp., for which there were only seven samples in which cell densities of $1.08 \times 10^{3}$ cell. $\mathrm{L}^{-1}$ were recorded. The highest cell density of the haptophytes (Imantonia sp.) was $3.72 \times 10^{3} \mathrm{cell}^{-\mathrm{L}^{-1}}$ and was found in the winter. This value decreased during the summer and autumn to $1.87 \times 10^{3}$ and $1.1 \times 10^{3} \mathrm{cell} \cdot \mathrm{L}^{-1}$, respectively, and Imantonia sp. was not present in spring (Figure 5(g)). The chlorophyte genus Eutreptiella sp. had different cell densities during the sampling. This genus' cell density was $1.8 \times 10^{3}, 1.44 \times 10^{3}$ and $1.0 \times 10^{3}$ cell $\cdot \mathrm{L}^{-1}$ in the spring, summer and autumn, respectively, and decreased during the winter (Figure $5(\mathbf{h})$ ). Prasinophytes, raphidophytes and cyanophytes had cell densities that were lower than $2.0 \times 10^{3} \mathrm{cell} \cdot \mathrm{L}^{-1}$ (Figure 5(h)). The prasinophytes, which were represented by the genus Tetraselmis sp., decreased from the spring to the autumn. The raphidophyte genus Heterosigma sp. was found occasionally from the winter to the summer (Figure 5(h)). During summer the cyanophyte genera Oscillatoria sp. was present in two samples and Anabaena sp. only in one sample, when these reached values of $2.0 \times 10^{3}$ and $1.8 \times 10^{3}$ for Oscillatoria sp. and $1.04 \times 10^{3} \mathrm{cell} \cdot \mathrm{L}^{-1}$ for Anabaena sp. However, Oscillatoria sp. did reach a density of $1.04 \times 10^{3} \mathrm{cell} \cdot \mathrm{L}^{-1}$ in one sample at the beginning of the autumn (Figure 5(h))

\subsection{Phytoplankton Pigments}

TChla concentrations differed throughout the year. The concentration reached $3.5 \mathrm{mg} \cdot \mathrm{m}^{-3}$ during the spring and the summer and decreased during the autumn and winter (Figure 6(a)). The highest concentration of fucoxanthin, which is the characteristic pigment of diatoms, was found in the summer $\left(2.0 \mathrm{mg} \cdot \mathrm{m}^{-3}\right)$ and decreased to $0.25 \mathrm{mg} \cdot \mathrm{m}^{-3}$ during the autumn (Figure 6(a)). The pigment alloxanthin, which is specific to cryptophytes, had concentrations of 0.83 and $0.7 \mathrm{mg} \cdot \mathrm{m}^{-3}$ in the spring and the summer, respectively (Figure 6(a)). The chlorophyll $b$ pigment was found in the summer and the autumn, when it reached concentrations of 0.84 and $0.35 \mathrm{mg} \cdot \mathrm{m}^{-3}$, respectively. However, its concentration was less in the winter and the spring (Figure 6(b)). Peridinin and zeaxanthin were not as common and had concentrations of only $0.2 \mathrm{mg} \cdot \mathrm{m}^{-3}$ during the sampling period (Figure 6(b), Figure 6(c)). DvChla was found in only six samples during the year (Figure 6(c)).

\subsection{Contribution of Phytoplankton to TChla}

The percentages of the contribution of each of the different phytoplankton groups, including those that could not be observed by inverted microscopy, were determined by means of CHEMTAX. The highest percentage (80\%) consisted of diatoms and occurred during the summer (Figure 7). The maximum value that was recorded for cryptophytes was $57 \%$, and their contribution was greater than $40 \%$ in the winter, the late spring and in some samples that were collected in the summer and early autumn. The contribution of dinoflagellates to TChla was less $20 \%$ during most of the year. However, this increased to $57 \%$ and $52 \%$ during the early spring and late autumn, respectively (Figure 7). The contribution of haptophytes was $20 \%$ in the winter and spring and decreased to $15 \%$ and $3 \%$ in the summer and autumn, respectively. The contribution of the cyanophytes to TChla was $22 \%$ in the winter, $17 \%$ in the spring and summer and $21 \%$ in the autumn. The contribution of the prochlorophytes to 

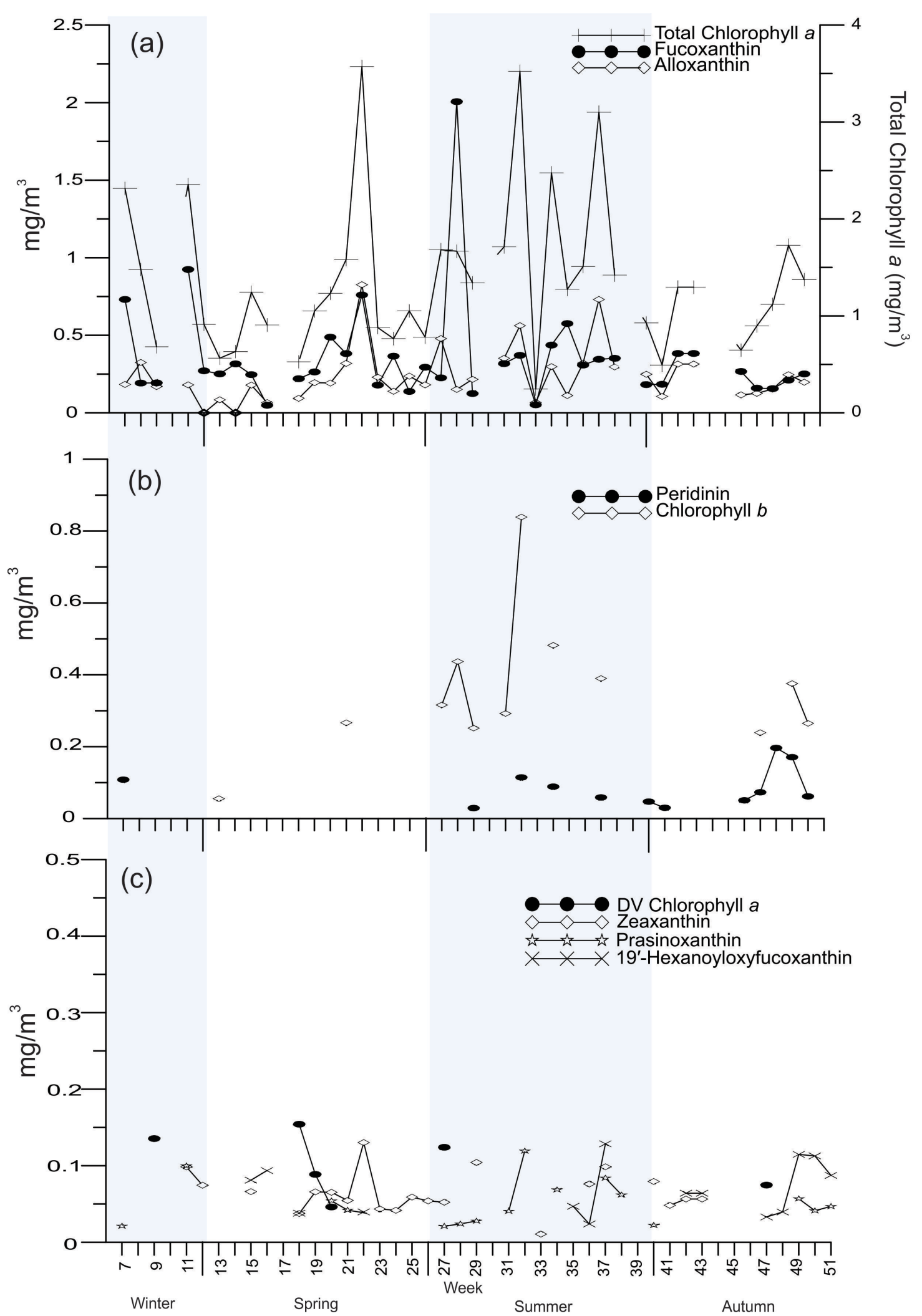

Figure 6. Concentration of pigments $\left(\mathrm{mg} \cdot \mathrm{m}^{-3}\right.$ ) for weekly sampling in 2011. Total chlorophyll (right axis), fucoxanthin, alloxanthin (left axis) (a), peridinin, chlorophyll $b$ (b), divinyl chlorophyll $a$, zeaxanthin, prasinoxanthi and 19'-Hexanoyloxyfucoxanthin (c). 


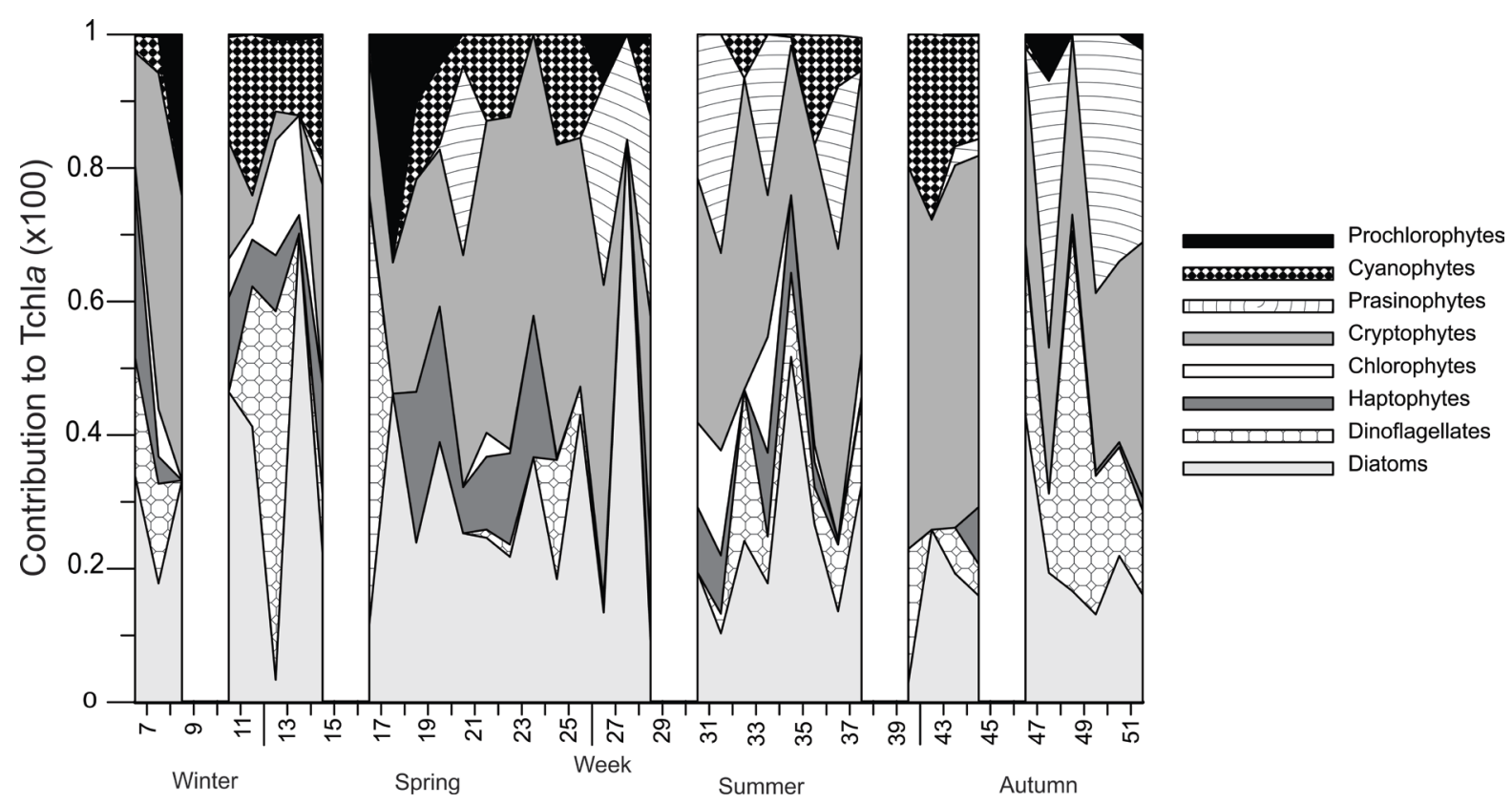

Figure 7. Contribution of the different phytoplankton groups to total chlorophyll $a$ as determined by CHEMTAX, for weekly sampling in 2011.

TChla was substantial in only six of the samples and averaged 15\% during the winter, 24\% in the spring and 7\% during the summer and autumn (Figure 7).

\section{Discussion}

The waters that are adjacent to SQB are affected by the California Current, which moves toward the interior of the bay due to tidal currents. These currents and upwelling processes are responsible for seasonal variations in nutrient inputs [4] [13]. Phytoplankton variation occurs in different patterns. There are cycles, tendencies, fluctuations, unusual events and irregular pulses, all at temporal scales of hours, days, seasons, years, decades or even longer periods. The variation can sometimes occur chaotically at several time scales and frequencies [21]. These fluctuations are not merely stochastic, but are instead the result of interactions among the physicochemical variables and biological parameters that control phytoplankton succession, upwelling and population dynamics [21]. Spring blooms are common in mild coastal systems. There is increasing evidence that changes in the phenology, abundance and composition of phytoplankton in recent decades may be related to climate change [23] [24]. The results of studies that were conducted by Guinder et al. (2013) [25] between 1978 and 2008 in the Blanca Bay estuary in Argentina showed that the abundance of phytoplankton communities in the austral summer was greater toward the end of the study but the concentrations of chlorophyll remained constant throughout the time series.

The upwelling index was greater than $60 \mathrm{~m}^{3} \cdot \mathrm{s}^{-1}$ per $100 \mathrm{~m}$ coastline during the spring and summer of 2011. These values resulted from wind velocities that were greater than $5 \mathrm{~m} \cdot \mathrm{s}^{-1}$, which caused an increase in phytoplankton abundance that was possibly due to nutrient inputs and high solar radiation. This phenomenon has also been reported [4] [6], but the diatoms Pseudo-nitzschia sp., Chaetoceros sp., Skeletonema sp. and Guinardia sp. were the most abundant phytoplankton species in the present study (Figure 5(a), Figure 5(b) and Figure 5(d)). Additionally, [4] Millán-Núñez et al. (1982) reported cell densities of $2.58 \times 10^{3} \mathrm{cell} \cdot \mathrm{L}^{-1}$ in the interior of the lagoon during the summer (during the months of June and July) and noted that diatoms and dinoflagellates were most abundant during these seasons. Gracia-Escobar et al. (2014) [7] showed that phytoplankton abundance during the autumn (in October, 2004) was 50\% of the phytoplankton abundance that was recorded during upwelling events that occurred in June of the same year [6]. These studies highlight the importance of physical and chemical factors and upwelling events in the increase in biomass and in determining the composition of the phytoplankton community in the interior of SQB. Analysis of the Pacific Decadal Oscillation index (PDO) showed that there were negative anomalies in sea surface temperature off the Baja California coast at the end of 
2010 that were due to La Niña. Temperatures decreased gradually toward the middle of 2011 and increased toward the middle of 2012 [26]. Oceanographic conditions in areas that were adjacent to SQB in 2011 were different from those that were observed during 2004 [6] [7]. However, diatoms were the most abundant group in both cases.

The greater abundance of diatoms was confirmed by microscopy and by the concentration of fucoxanthin, which is characteristic of diatoms. Fucoxanthin concentration varied only slightly throughout the year. The maximum values were observed in July and resulted from a bloom of the genus Chaetoceros sp. (Figure 5(a)). This increase is consistent with the proportion of their contribution to TChla that was determined by CHEMTAX. Diatoms of the genera Chaetoceros sp., Pseudo-nitzschia sp. and Skeletonema sp. accounted for $80 \%$ of TChla (Figure 5(a), Figure 5(b) and Figure 5(d)).

Dinoflagellates were less abundant, which can be inferred from the lower concentrations of peridinin, which is specific to dinoflagellates (Figure 6(b)). During the early spring and autumn, the proportional contribution of dinoflagellates to TChla was greater. However, the peridinin concentrations and dinoflagellate abundance that were observed in the autumn occurred during periods with lower upwelling indices (Figure 2(c), Figure 5(e), Figure 5(f)).

The cryptophytes were the most abundant nanophytoplankton. Two different genera, Hillea sp. and Leucocryptos sp., were found (Figure 5(g)). However, Moreno-Miranda (2007) [6] found that the genus Chroomonas sp. was also present in SQB. This could be explained by the hydrological conditions that were present during the different sampling periods and by the fact that cryptophytes are found in coastal and estuarine waters that have high concentrations of organic matter and less light availability [27]. The water in the interior of SQB is shallow, and light penetration is limited by the high concentration of detritus. This is especially true in and near the Falsa Bay, in which the presence of several bivalve hatcheries and the effect of tides favor the growth and distribution of cryptophytes.

Prochlorophytes were observed in some of the 2011 samples and contributed 32\% to TChla in the spring (Figure 7). These values are lower than those that were reported by Millán-Núñez et al. (2004) [10] and were due to the low temperatures that occurred during 2011 and that were associated with la Niña during the same year, which was the year that the present study was conducted [26]. Prochlorococcus sp. is normally found in oligotrophic warm waters [28].

Chlorophytes and prasinophytes have a characteristic pigment, chlorophyll $b$ [18]. Prasinophytes also have another specific pigment, prasinoxanthin. The contribution of prasinoxanthin to TChla was $20 \%$ during the summer and autumn of 2011 (Figure 7). Millán-Núñez et al. (2004) [10] and Moreno-Miranda (2007) [6] observed that the contribution of prasinophytes to TChla was 10\% during April, 2001 and June, 2004. Gracia-Escobar et al. (2014) [7] reported percentages of $20 \%$ during high tides in 2004. The present study suggests that the cell density of prasinophytes is low in Falsa Bay. The variability of chlorophyll $b$ can therefore be attributed to the presence of chlorophytes, particularly the genus Eutreptiella sp., which had high cell concentrations from the spring to the autumn (Figure 6(b)) and contributed 17\% to TChla during the spring and summer (Figure 7). However, chlorophyll $b$ can also be found in macroalgae and vascular plants [29]. The biomass of Ulva sp. and Zostera marina is variable, but it is large in SQB throughout the entire year. The largest biomass of these genera is found in June and July, when productivity is limited by nitrogen [30] [31]. The reproductive cells of some macroalgae have a planktonic life cycle [32] and are transported by tidal currents, which could account for the high concentrations of chlorophyll $b$ in the spring and autumn in the sampling area. However, Z. marina is more abundant during September and October when productivity is limited by lower light levels, lower temperature and fewer nutrients [31].

\section{Conclusion}

This is the first study to be conducted in SQB that is based on weekly sampling of phytoplankton abundance and biomass throughout an entire year. There were 16 positive z-scores that were obtained from total phytoplankton abundance on average for 2011. However, only three had values of at least 1.66 standard deviations above the mean, and they corresponded to blooms that occurred during upwelling events in the winter, spring and summer. This confirms the importance of nutrient inputs toward the interior of the bay as a limiting factor of phytoplankton productivity. The predominant genera during the blooms accounted for $80 \%$ of phytoplankton cells, but the genera differed in each bloom. The first bloom consisted of diatoms of the genera Pseudo-nitzschia sp., Skele- 
tonema sp., Eucampia sp. and Navicula sp., the haptophyte Imantonia sp., and the dinoflagellate, Prorocentrum sp. The second bloom consisted of diatoms of the genera Guinardia sp., Pseudo-nitzschia sp., Skeletonema sp., Chaetoceros sp. and Eucampia sp. The third consisted of Chaetoceros sp., Pseudo-nitzschia sp., Skeletonema sp. and the haptophyte, Imantonia sp. The most abundant groups in the blooms were the diatoms Chaetoceros sp., Pseudo-nitzschia sp., Guinardia sp., Eucampia sp. and Skeletonema sp. The abundance, groups and phytoplankton genera differed in each bloom, which most likely resulted from changes in physical and chemical factors that control phytoplankton growth and upwelling events during 2011.

\section{Acknowledgements}

We are grateful to the National Council of Science and Technology (México) for the PhD scholarship. We are also grateful to Dr. José Antonio Zertuche González and to José Manuel Guzmán Calderón, who was in charge of field and laboratory operations of the Integrated Aquaculture Project: Macroalgae, abalones and oysters in Falsa Bay. We are also grateful to Dra. Elizabeth Orellana, who assisted to phytoplankton identification, and to the physical oceanography group of the Instituto de Investigaciones Oceanologicas of the Universidad Autónoma de Baja California for providing access to the wind data.

\section{References}

[1] Lara-Lara, J.R. and Álvarez-Borrego, S. (1975) Ciclo anual de la clorofila y producción orgánica en la Bahía de San Quintín B.C. Ciencias Marinas, 2, 77-96.

[2] Álvarez-Borrego, S. and Najera de Muñoz, S. (1979) Series de tiempo de fitoplancton en dos lagunas costeras de Baja California. Ciencias Marinas, 6, 1-19.

[3] Lara-Lara, J.R., Álvarez-Borrego, S. and Small, L.F. (1980) Variability and Tidal Exchange of Ecological Properties in a Coastal Lagoon. Estuarine and Coastal Marine Science, 2, 613-637. http://dx.doi.org/10.1016/S0302-3524(80)80014-4

[4] Millán-Núñez, R., Álvarez-Borrego, S. and Nelson, D.M. (1982) Effects of Physical Phenomena on the Distribution of Nutrients and Phytoplankton Productivity in a Coastal Lagoon. Estuarine Coastal and Shelf Science, 15, 317-335. http://dx.doi.org/10.1016/0272-7714(82)90066-X

[5] Silva-Cota, S. and Álvarez-Borrego, S. (1988) The "EL NIÑO” Effect on the Phytoplankton of a North-Western Baja California Coastal Lagoon. Journal of Coastal Shelf Science, 27, 109-115.

[6] Moreno-Miranda, C. (2007) Variabilidad espacial de la composición taxonómica del fitoplancton en Bahía San Quintín. Msc Thesis, Facultad de Ciencias Marinas, U. A. B. C., Ensenada, B.C. 81 pp.

[7] Gracia-Escobar, M.F., Millán-Núñez, R., González-Silvera, A., Santamaría-del-Ángel, E., Camacho-Ibar, V.F. and Trees, C.C. (2014) Changes in the Abundance and Composition of Phytoplankton in a Coastal Lagoon during NeapSpring Tide Conditions. Open Journal of Marine Science, 4, 80-100. http://dx.doi.org/10.4236/ojms.2014.42010

[8] Tester, P., Geesey, M., Guo, C., Paerl, H. and Millie, D. (1995) Evaluating Phytoplankton Dynamics in the Newport River Estuary (North Carolina, USA) by HPLC-Derived Pigment Profiles. Marine Ecology Progress Series, 24, 237245. http://dx.doi.org/10.3354/meps124237

[9] Mackey, M.D., Mackey, D.J., Higgins, H.W. and Wright, S.W. (1996) CHEMTAX-A Program for Estimating Class Abundances from Chemical Markers: Application to HPLC Measurements of Phytoplankton. Marine Ecology Progress Series, 114, 265-283. http://dx.doi.org/10.3354/meps144265

[10] Millán-Núñez, R., Millán-Núñez, E., Álvarez-Borrego, S. Trees, C.C., and Santamaría-del-Ángel, E. (2004) Variabilidad de la comunidad del fitoplancton en Bahía San Quintín estimada mediante el análisis de pigmentos. Ciencias Marinas, 30, 35-43.

[11] Partensky, F., Hess, W.R. and Vaulot, D. (1999) Prochlorococcus, a Marine Photosynthetic Prokaryote of Global Significance. Microbiology and Molecular Biology Reviews, 63, 106-127.

[12] Barnard, J.L. (1962) Benthic Marine Exploration of the Bahia San Quintín, Baja California, 1960-1961. Pacific Naturalist, 2, 251-269.

[13] Ribas-Ribas, M., Hernández-Ayón, J.M., Camacho-Ibar, V.F., Cabello-Pasini, A., Mejia-Trejo, A., Durazo, R., Galindo-Bect, S., Souza, A.J., Forja, J.M. and Siqueiros-Valencia, A. (2011) Effects of Upwelling, Tides and Biological Processes on the Inorganic Carbon System of a Coastal Lagoon in Baja California. Estuarine, Coastal and Shelf Science, 95, 367-376. http://dx.doi.org/10.1016/j.ecss.2011.09.017

[14] Utermöhl, H. (1958) Zur Vervollkommnung der quentitativen Phytoplankton-Methodik. Mitteilungen der International Vereinigung fur heorestische und Angewandte Limnologie, 9, 1-38. 
[15] Intergovernmental Oceanographic Commission of UNESCO (2010) Microscopic and Molecular Methods for Quantitative Phytoplankton Analysis. Karlson, B., Cusack, C. and Bresna, E., Eds., Manuals and Guides, UNESCO, Paris.

[16] Santamaría-del-Ángel, E. (1988) Variación fitoplanctónica en Puerto Don Juan, Bahía de los Ángeles, Baja California México. Tésis de Maestría en Oceanografía Costera, Facultad de Ciencias Marinas, UABC, Ensenada, 153 p.

[17] Barlow, R.G., Cummings, D.G. and Gibb, S.W. (1997) Improved Resolution of Mono- and Divinyl Chlorophylls $a$ and $b$ and Zeaxanthin and Lutein in Phytoplankton Extracts Using Reverse Phase C-8 HPLC. Marine Ecology Progress Series, 161, 303-307. http://dx.doi.org/10.3354/meps161303

[18] Jeffrey, S.W., Mantoura, R.F.C. and Wright, S.W. (1997) Phytoplankton Pigments in Oceanography: Guidelines and Modern Methods. UNESCO Publishing, Paris, 661 p.

[19] Lionard, M., Muylaert, K., Tackx, M. and Vyverman, W. (2008) Evaluation of the Performance of HPLC-CHEMTAX Analysis for Determining Phytoplankton Biomass and Composition in a Turbid Estuary (Schelde, Belgium). Estuarine, Coastal and Shelf Science, 76, 809-817. http://dx.doi.org/10.1016/j.ecss.2007.08.003

[20] Pérez-Brunius, P., Lopéz, M., Parés-Sierra, A. and Pineda, J. (2007) Comparison of Upwelling Indices off Baja California Derived from Three Different Wind Data Sources. California Cooperative Oceanic Fisheries Investigations Reports, 48, 204-214.

[21] Smayda, T.J. (1998) Patterns of Variability Characterizing Marine Phytoplankton, with Examples from Narragansett Bay. ICES Journal of Marine Science, 55, 562-573. http://dx.doi.org/10.1006/jmsc.1998.0385

[22] Carstensen, J., Henriksen, P. and Heiskanen, A.S. (2007) Summer Algal Blooms in Shallow Estuaries: Definition, Mechanisms, and Link to Eutrophication. Limnology and Oceanography, 52, 370-384. http://dx.doi.org/10.4319/lo.2007.52.1.0370

[23] Hays, G.C., Richardson, A.J. and Robinson, C. (2005) Climate Change and Marine Plankton. Trends in Ecology \& Evolution, 20, 337-344. http://dx.doi.org/10.1016/j.tree.2005.03.004

[24] Parmesan, C. (2006) Ecological and Evolutionary Responses to Recent Climate Change. Annual Review of Ecology, Evolution, and Systematics, 37, 637-669. http://dx.doi.org/10.1146/annurev.ecolsys.37.091305.110100

[25] Guinder, A.V., Popovich, C.A., Molinero, J.C. and Marcovecchio, J. (2013) Phytoplankton Summer Bloom Dynamics in the Bahía Blanca Estuary in Relation to Changing Environmental Conditions. Continental Shelf Research, 52, 150158. http://dx.doi.org/10.1016/j.csr.2012.11.010

[26] Bjorkstedt, E.P., Goericke, R., McClatchie, S., Weber, E., Watson, W., Lo, N., William, T., et al. (2012) State of the California Current 2011-2012: Ecosystems Respond to Local Forcing as La Niña Wavers and Wanes. California Cooperative Oceanic Fisheries Investigations Reports, 53, 41-76.

[27] Lepisto, L. and Holopainen, A.L. (2003) Occurrence of Cryptophyceae and Katablepharids in Boreal Lakes. Hydrobiologia, 502, 307-314. http://dx.doi.org/10.1023/B:HYDR.0000004288.74485.52

[28] Letelier, R.M., Bidigare, R.R., Hebel, D.V., Ondruseck, M., Winn, C.D. and Karl, D.M. (1993) Temporal Variability of Phytoplankton Community Structure Based on Pigment Analysis. Limnology and Oceanography, 38, 1420-1437. http://dx.doi.org/10.4319/lo.1993.38.7.1420

[29] Abd El-Baky, H., El Baz, F.K. and El-Baroty, G.S. (2008) Evaluation of Marine Alga Ulva lactuca L. as a Source of Natural Preservative Ingredient. American-Eurasian Journal of Agricultural and Environmental Science, 3, 434-444.

[30] Aveytua-Alcázar, L., Camacho-Ibar, V.F., Souza, A.J., Allen, J.I. and Torres, R. (2008) Modelling Zostera marina and Ulva spp. in a Coastal Lagoon. Ecological Modelling, 218, 354-366. http://dx.doi.org/10.1016/j.ecolmodel.2008.07.019

[31] Zertuche-González, J.A., Camacho-Ibar, V.F., Pacheco-Ruíz, I., Cabello-Pasini, A., Galindo-Bect, L., Guzmán-Calderón, J., Macias-Carranza, V. and Espinoza-Avalos, J. (2009) The Role of Ulva spp. as a Temporary Nutrient Sinks in a Coastal Lagoon with Oyster Cultivation and Upwelling Influence. Journal of Applied Phycology, 21, 729-736. http://dx.doi.org/10.1007/s10811-009-9408-y

[32] Beach, K.S., Smith, C.M., Michael, T. and Shin, H.W. (1995) Photosynthesis in Reproductive Unicells of Ulva fasciata and Enteromorpha flexuosa: Implications for Ecological Success. Marine Ecology Progress Series, 125, $229-237$. http://dx.doi.org/10.3354/meps125229 